www.mjn.mosuljournals.com

\title{
Assessment Barbers Knowledge's and Practice's About Hepatitis Virus In Mosul City
}

Article information

Article history:

Received February 12, 2018

Accepted May 22, 2019

Available online May 18, 2018

\author{
DOI: 10.33899/mjn.2018.160080 @2020, College of Nursing, University of Mosul. \\ Creative Commons Attribution 4.0 International License \\ https://mjn.mosuljournals.com/article_160080.html
}

\section{Handay Jabbar Mahmood ${ }^{1} \quad$ Ekhlas Tariq Hassan $^{2}$}

\begin{abstract}
Background and objective: The liver plays an important role and vital that processes nutrients, filters the blood, and fights infections. Irritate or injured in the liver, its function can be affected. Heavy alcohol use, toxins, some medications, and certain medical conditions can cause hepatitis. The study objective is to assess the knowledge's and practice's of barbers about occupational safety

Material and methods: Design of the study was cross-sectional descriptive to achieve the objectives of the present study from (17th February 2018) to (30th July 2018). A randomized cross-sectional survey of (60) barber / Mosul City. The sample comprises male and age groups between (15->45) year. The questionnaire which corrects from the expert's opinion, and used the Coefficient Correlation for items which showed that the reliability estimate for the survey was $(r=0.88)$ that was significant at $(P<0.05)$ level.

Result: The study showed a high percentage of barbers aged between $(25-35)$ year $(30 \%)$. The analysis of data revealed that $(53.33 \%)$ of barbers hadn't good perception toward their knowledge and showed that $(58.33 \%)$ of barbers haven't good practices toward their occupational safety. The study founded the significant relationship between demographical data (educational level, marital status and license to practice the profession) and knowledge, also the vital connection between demographical data (license to practice the job) and practices.

Conclusion: Our study finds out a marked lower in the information and practices of the barbers working in the Mosul city.

Recommendation: Launching health education programs for professionals who are related to individuals in the community. Behavior exchange campaigns for barbers and focuses on them with the aid of occupational safety committees.

Key word: Hepatitis, Barbers, Knowledge, Practices.
\end{abstract}

\footnotetext{
${ }^{1}$ Assistant professor Mosul University / Nursing College
}

${ }^{2}$ Chief programmer Mosul University / Nursing College 


\section{Mosul Journal of Nursing, Vol. 6, No. 1, 2018 ( 34-40 )}

\section{Introduction}

Least five different viruses hepatitis is A virus (HAV), hepatitis B (HBV), hepatitis $\mathrm{C}(\mathrm{HCV})$, hepatitis D virus (HDV), and hepatitis E virus (HEV), causes infection in the liver(Surveillance, 2015). In worldwide, found over 2 billion human beings had infected with HBV and 170 million HCV contaminated patients, that according to world health organization. HBV is 50 to a hundred times more infectious than the Human Immunodeficiency Virus (HIV)(Averhoff, 2012). Occupational safety in most developing countries, there is a gap between policy making and its implementation. Among the professional groups affected by this situation are barbers. Occupational safety regulations, for barbers, there are no mechanisms in place to ensure registration and compliance. The use of blades and razors is part of barbers work which can expose them to the blood of customers while shaving and hair cutting. Chance of any blood-borne illnesses such as hepatitis B result from this exposure. (Jokhio et al., 2010). The originated word 'barber' from the Latin word. A person whose occupation is to cut any hair, give shaves, and trim beards is a barber. Among the sites that are very important in phrases of environmental and personal fitness is a barbershop that helps in improving public health level and ailment control. Transmission of particular types of pores and skin ailments and blood infections is inevitable in case of lack of attention to this issue (Wazir et al., 2008). Education and raising the society's level of health information are continuous and dynamic processes. Currently, the best way to prevent and control the diseases spread is education and correcting the risk group behaviors(Razi, 2010). Given to the personal hygiene and human environmental sanitation has unique importance, so controlling ecological factors play a crucial role in improving human health and environmental pollution that have specific diversity which can put at danger all physical, mental and social fitness of human being (Wazir et al., 2008)
The prevention of infectious diseases, with emphasis on high-risk groups, are the pillars of

policies and designed strategies of the organization raising the level of awareness and promoting the attitudes of society, this is the perspective of World Health Organization (WHO) (Pirsaheb et al., 2016). The objective of our current study is to assess the knowledges and practices of barbers about occupational safety risks in their work.

Material and method

Research design: Cross- sectional descriptive study design was adopted to achieve the objectives of the present study from $\left(17^{\text {th }}\right.$ February 2018) to $\left(30^{\text {th }}\right.$ July 2018).

Period of the study and data collection: The period of the study and data collection from $\left(17^{\text {th }}\right.$ February 2018$)$ to $\left(20^{\text {th }}\right.$ May 2018).

Setting: In Mosul City, our study conducted, the center of Nineveh province and the second largest city in Iraq regarding population after Baghdad. With a population of 2 million and a half million and Mosul away from Baghdad at a distance of about $465 \mathrm{~km}$.

Sample of the study: A randomized cross-sectional survey of (60) barbers / Mosul City. The sample includes only male and age groups between $(15-45>)$ year.

\section{Study instrument}

A self-administered structured questionnaire was used to collect data. To obtain study information, a poll constructed on previous studies and related literature. Interviewers visited the barbershops and requested barbers to participate in the study. We have conducted our survey through Face-to-face interviews conducted with participating barbers in the research. Before the start of collecting data, documented barber practices with the client through the questionnaire. The questionnaire is composed of three parts:-

Part one:- this part includes (6 items which focus on the barbers' demographical data such as (age, educational level, license to practice the job, and years of work, number of barbers, marital status. 
Part two:- Fifteen item consist of the general questions to assess knowledge of barbers' about of hepatitis such as (different modes of transmission of hepatitis, including the risk of transmission of the disease due to use and reuse of razors, and knowledge of vaccines and anthers knowledge) The overall question depended on two option (Yes, No). The response of the problem after correction divided into two groups (0) for not correctly answered and (1) for correctly answered.

Part three:- This part consist (15 items) Which is a focus on the barbers' practices.
A checklist was used by seeing hand washing before each customer, sterilizing the tools, changing the blades and throwing them before using them for the next customer and other practices. The overall observation depended on two option (Yes, No). The response of the inspection after correction divided into two groups (0) for not correctly an answered and (1) for correctly answered.

Statistical analysis: The data were analyzed using statistical analysis for social sciences (SPSS, version 22) and frequencies, percentage, mean, and standard deviation.

\section{Result:}

Table (1): Distribution study sample related to demographical data.

\begin{tabular}{|c|c|c|c|}
\hline \multicolumn{2}{|c|}{ Demographical Data } & Frequency & Percent \\
\hline \multirow{4}{*}{ Age } & $15-25$ & 16 & 26.67 \\
\hline & $25-35$ & 18 & 30.00 \\
\hline & $35-45$ & 12 & 20.00 \\
\hline & $>45$ & 14 & 23.33 \\
\hline \multicolumn{2}{|l|}{ Total } & 60 & 100 \\
\hline \multirow{2}{*}{ Marital status } & Single & 15 & 25 \\
\hline & Married & 45 & 75 \\
\hline \multicolumn{2}{|l|}{ Total } & 60 & 100 \\
\hline \multirow{5}{*}{ Educational Level } & Read and wright & 7 & 11.67 \\
\hline & Primary & 13 & 21.67 \\
\hline & Secondary & 23 & 38.33 \\
\hline & Institute & 16 & 26.67 \\
\hline & College & 1 & 1.67 \\
\hline \multicolumn{2}{|l|}{ Total } & 60 & 100 \\
\hline \multirow{4}{*}{ Years of experience in barbers } & $1-10$ & 29 & 48.33 \\
\hline & $10-20$ & 15 & 25.00 \\
\hline & $20-30$ & 9 & 15.00 \\
\hline & $>30$ & 7 & 11.67 \\
\hline \multirow{3}{*}{ license to practice the job } & & 60 & 100 \\
\hline & Yes & 51 & 85.00 \\
\hline & No & 9 & 15.00 \\
\hline \multirow[t]{2}{*}{ Total } & & 60 & 100 \\
\hline & 1 & 25 & 41.67 \\
\hline \multirow{3}{*}{ Number of barbers in shop } & 2 & 28 & 46.67 \\
\hline & 3 & 6 & 10.00 \\
\hline & 4 & 1 & 1.67 \\
\hline Total & & 60 & 100 \\
\hline
\end{tabular}




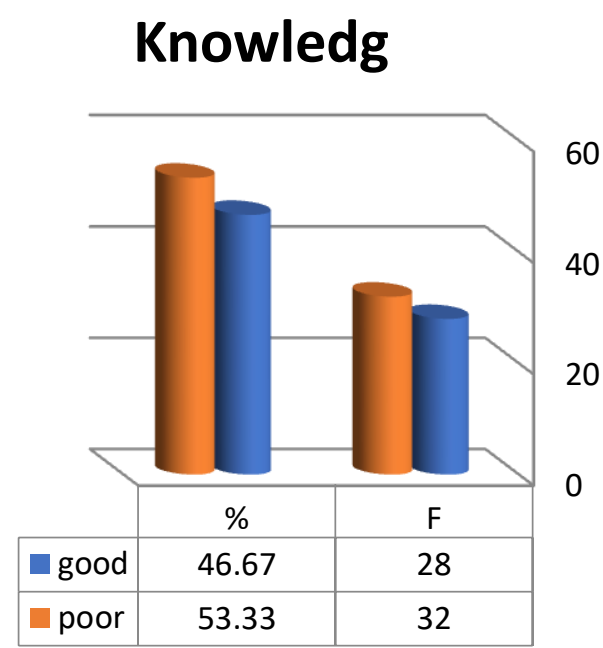

Figure (1): Distribution of barbers to level knowledge's barbers

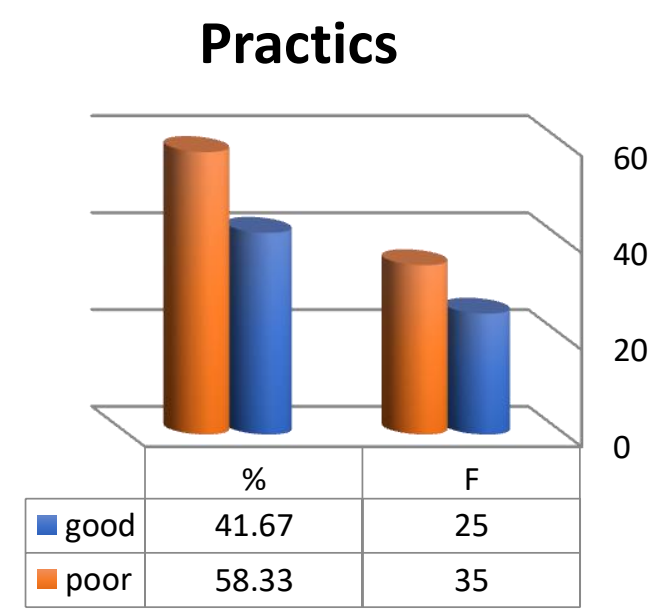

Figure (2): Distribution of barber to level barbers practicing for occupational safety

Table (2): One -way analysis of variance for the difference between knowledge, age, educational level, years of experience in barbers, license to practice the profession, Number of barbers in the shop and marital status.

\begin{tabular}{c|cccccc}
\hline \multirow{2}{*}{ Category } & Source of Variance & $\begin{array}{c}\text { Sum of } \\
\text { Squares }\end{array}$ & df & $\begin{array}{c}\text { Mean } \\
\text { Square }\end{array}$ & F & Sig. \\
\hline \multirow{4}{*}{ Age } & Between Groups & 24.47 & 13 & 1.88 & & \\
& Within Groups & 49.93 & 46 & 1.09 & 1.73 & 0.09 \\
& Total & 74.40 & 59 & & & \\
Marital status & Between Groups & 5.56 & 13 & 0.43 & & \\
& Within Groups & 5.69 & 46 & 0.12 & 3.46 & 0.00 \\
Educational Level & Total & 11.25 & 59 & & & \\
& Between Groups & 30.59 & 13 & 2.35 & & \\
Years of experience in & Within Groups & 29.06 & 46 & 0.63 & 3.73 & 0.00 \\
barbers & Total & 59.65 & 59 & & & \\
& Between Groups & 19.03 & 13 & 1.46 & & \\
license to practice the & Within Groups & 46.37 & 46 & 1.01 & 1.45 & 0.17 \\
profession & Total & 65.40 & 59 & & & \\
& Between Groups & 4.96 & 13 & 0.38 & & \\
Within Groups & 2.69 & 46 & 0.06 & 6.52 & 0.00 \\
Number of barbers in & Total & 7.65 & 59 & & & \\
shop & Between Groups & 8.84 & 13 & 0.68 & & \\
& Within Groups & 21.35 & 46 & 0.46 & 1.46 & 0.17 \\
& Total & 30.18 & 59 & & &
\end{tabular}

Table (3): One -way analysis of variance for the difference between practices, age educational level, years of experience in barbers, license to practice the profession, Number of barbers in the shop and Marital status

\begin{tabular}{c|cccccc}
\hline Category & Source of Variance & $\begin{array}{c}\text { Sum of } \\
\text { Squares }\end{array}$ & df & $\begin{array}{c}\text { Mean } \\
\text { Square }\end{array}$ & F & Sig. \\
\hline \multirow{3}{*}{ Age } & Between Groups & 12.98 & 10 & 1.30 & & \\
& Within Groups & 61.43 & 49 & 1.25 & 1.04 & 0.43 \\
Marital status & Total & 74.40 & 59 & & & \\
& Between Groups & 2.92 & 10 & 0.29 & 1.72 & 0.10
\end{tabular}




\begin{tabular}{c|cccccc} 
& Within Groups & 8.33 & 49 & 0.17 & & \\
& Total & 11.25 & 59 & & & \\
Educational Level & Between Groups & 11.15 & 10 & 1.12 & & \\
& Within Groups & 48.50 & 49 & 0.99 & 1.13 & 0.36 \\
& Total & 59.65 & 59 & & & \\
Years of experience in & Between Groups & 10.83 & 10 & 1.08 & & \\
barbers & Within Groups & 54.58 & 49 & 1.11 & 0.97 & 0.48 \\
& Total & 65.40 & 59 & & & \\
license to practice the & Between Groups & 2.81 & 10 & 0.28 & & \\
profession & Within Groups & 4.84 & 49 & 0.10 & 2.84 & 0.01 \\
& Total & 7.65 & 59 & & & \\
Number of barbers in & Between Groups & 2.89 & 10 & 0.29 & & \\
shop & Within Groups & 27.29 & 49 & 0.56 & 0.52 & 0.87 \\
& Total & 30.18 & 59 & & &
\end{tabular}

\section{Discussion}

This study to assesses the knowledge toward hepatitis regarding a knowledge, and practices of the barbers employed in Mosul city. The region where the popular public is prone to different infectious illness including Hepatitis B, C, HIV/AIDS, and skin contagions is a barbershop. So, the disease extent can be due to contaminated instruments or towels. In our study table (1) shows the highest percentage $(30 \%)$ of the sample was the age group $(25-35)$ years, but low percentage (20\%) in the age group (3545) years. A marital status, $(75 \%)$ of the participant was married. The highest percentage of educational level was $(38.33 \%)$ who were the secondary school certificate. The percentage of those who have experience working at $(48.44 \%)$ for the period from $(1-10)$ years. Licensed to practice the profession was at the rate of pumping $(85 \%)$ and the percentage of married $(75 \%)$, the percentage number of barbers working in the shop was $(46.67 \%)$. Table (2): Shows that there were significant differences between barbers license to practice the profession, marital status and their educational level at $\mathrm{P}$ value $\leq(0.05)$. Table (3): Shows that there were no significant differences between barbers practices Stowed hepatitis regarding educational degree, marital status, years of experience in the barber, license to practice the profession, number of barbers in the shop, marital status and their age at $\mathrm{P}$ value $\leq 0.05$. Our study finds out about displays the organic risks associated with barbers' expertise and practice of their work in the Mosul City. Thus, out of the complete find out about subjects, about 28 (48,67\%) have applicable awareness about organic dangers associated to their work, which is lower than the studies performed in Gondar, Ethiopia (78\%) (Beyen et al., 2012), Pakistan, Kharian City of Gujrat District (42\%) (Wazir et al., 2008), Rawalpindi and Islamabad (39.6\%) (Waheed et al., 2010), Bahra Kahu, Islamabad (38\%) and (Chaudhry et al., 


\section{Mosul Journal of Nursing, Vol. 6, No. 1, 2018 ( 34-40 )}

2010). In this study, the barbers' practices to decrease biological hazards related to their work is slightly low. Accordingly, about 25 (41.67\%) practices safely to avert biological risks associated with their work. This finding is lower than the research carried out in Jimma Ethiopia, Pakistan; Kharian City of Gujrat District (Wazir et al., 2008), Bahra Kahu, Islamabad (Chaudhry et al., 2010), Rawalpindi and Islamabad and Sana'a City, Yemen (AlRabeeI and Dallak, 2011). Barbers are now no longer paying interest to the care and threat elements associated with their occupation in the prevention of disease, but they are paying more attention to the decoration, air conditioning, sound system, and availability of television in the shop. Even the barbers working in stores in posh areas have less than secondary stage education. Most barbers commenced their exercise at a decidedly youthful age of 10 - 12 years, at such an infantile age they have no thinking about the transmission of

\section{References}

Al-RabeeI NA, Dallak AM (2011). Knowledge, attitudes and practices of barbers regarding Hepatitis $\mathrm{B}$ and $\mathrm{C}$ viral infection in Sana'city, Yemen. J. Commun. Health 35:935-939.

Averhoff F, (2012): Infectious diseases related to travel, Centers for Disease Control and Prevention (CDC): Travelers' health, Chapter 3, p 78.

http://wwwnc.cdc.gov/travel/yellowbo ok/2014/chapter-3-infectious-diseasesrelated-to-travel/hepatitis-b.

Beyen T, Tulu K, Abdo A, Tulu A (2012). Barbers' knowledge and practice about occupational biological hazards was low in Gondar town, illnesses from the gadgets used. Barbers themselves may also often be uncovered by chance to the blood and bodily fluids of their clients.

\section{Conclusion:}

Our study explained that the knowledge of barbers is under the required level and that their degrading practices are not appropriate and this has a negative impact on society directly.

\section{Recommendation:}

Our study recommended launching health education programs for professionals who are related to individuals in the community. Initiate a change campaign focusing on changing the behavior of barbers to maintain their safety first and second the general population. Health control should play an essential role in spreading awareness of society, especially barbers and other professions that have direct relation with the people of community.

North West Ethiopia. BMC Public Health 12(942).

Chaudhry M, Ashraf M, Afzal M, Niazi S (2010). Knowledge and practices of barbers regarding hepatitis $\mathrm{B}$ and hepatitis C in Bahra Kahu, Islamabad-Pakistan. Rawal Med. J. 35(1):37-40.

Http://www.wikipedia.org.com Barber 2013 [cited 201505 May].

Downey C. (2006), Can salons spread infection. Available from: http://healthlibrary.epnet.com/print.asp x. Accessed: December 2.

Jokhio A, Bhatti T, Memon S., (2010)

Knowledge, attitudes and practices of barbers about hepatitis B and C 
transmission in Hyderabad, Pakistan. East Mediterr Health J; 16:1079-84. Pirsaheb M, Atafar Z, Dargahi A, Asadi F, Karami A, Rezaei F. (2016) Prevalence of hepatitis B and its associated factors among barbers in Kermanshah province (2008-11). J Kermanshah Univ Med Sci. 19(7):446-51. (Full Text in Persian). Razi A, Rehman R, Naz S, Ghafoor F, Khan MA. (2010), Knowledge attitude and practice of university stududent regarding hepatitis B and C. J Agric Biol Sci, 5(4):38-43.

Surveillance for Viral Hepatitis United States, 2015.

Waheed Y, Safi S, Chaudhry W, Qadri I (2010). Awareness and risk factors associated with barbers in transmission of hepatitis B and C from Pakistani population: barber's role in viral transmission. Asian Biomed. 4(3):435-442.

Wazir MS, Mehmood S, Ahmed A, Jadoon HR., (2008) Awareness among barbers about health hazards associated with their profession. J Ayub Med Coll Abbottabad, 20(2):358. 